\title{
Androgens and cardiac diseases
}

\section{Androgeni e cardiopatie}

\author{
Vittorio Bianchi ${ }^{1}$, Alessandro Mezzani2
}

\begin{abstract}
Androgens and cardiac diseases. V. Bianchi, A. Mezzani.

Although androgens have been considered deleterious for the cardiovascular system, recent data have demonstrated favourable testosterone effects on cardiac and vascular remodeling and clinical outcome. However, the cardiovascular risk-benefit profile of testosterone therapy remains largely elusive due to lack of well-designed and adequately powered randomized clinical trials. In any case, a large body of clinical evidence underlines that low plasma testosterone levels should be considered a risk factor for
\end{abstract}

\begin{abstract}
cardiovascular disease, and that the evaluation of sex steroids should be included in the routine clinical evaluation of cardiac patients. A better understanding of the mechanism regulating the effects of testosterone on cardiovascular system could lead to novel therapeutic strategies in several cardiac patient populations, such as chronic heart failure patients and those who recently underwent cardiac surgery.

Keywords: testosterone, androgens, cardiac disease, cardiovascular risk.
\end{abstract}

Monaldi Arch Chest Dis 2013; 80: 161-169.

1 Clinical Center Stella Maris - Exercise Physiology Laboratory - Falciano - Repubblica di San Marino.

2 Salvatore Maugeri Foundation, IRCCS - Scientific Institute of Veruno - Cardiac Rehabilitation Division - Exercise Pathophysiology Laboratory - Veruno (NO) - Italy.

Corresponding author: Dr. Vittorio Bianchi; Clinical Center Stella Maris - Exercise Physiology Laboratory; Strada Rovereta, 42; I-47891 Falciano, Repubblica di San Marino; Fax: +39-0549942779; E-mail address: dott.vbianchi@gmail.com

\section{Androgens in normal humans}

Human androgens comprise testosterone ( $\mathrm{T}$ ), dihydrotestosterone (DHT), androstenedione and dehydroepiandrosterone (DHEA) and its sulfate. Most of $\mathrm{T}$ is secreted by the testis in males and by the ovary in females. Approximately 5\% of serum $\mathrm{T}$ is transformed in DHTby a $5 \alpha$-reduction process, with DHT having a threefold greater affinity than $\mathrm{T}$ and a 15- to 30-fold greater affinity than adrenal androgens for androgen receptors. DHEA and dehydroepiandrosterone sulfate, the most abundant adrenal steroids in humans, are precursors of the intracellular production of androgens and estrogens in non-reproductive tissues. Most T is bound to plasma proteins, namely, $40-50 \%$ to albumin and $50-60 \%$ to sex hormone-binding globulin, with $1-2 \%$ being free [1]. Part of $T$ is converted by the aromatase enzyme in estradiol, so that $\mathrm{T}$ is active through three ways: i) by directly activating the androgen receptors, ii) by indirectly activating the androgen receptors as DHT, and iii) by activating the estrogen receptors $\alpha$ and $\beta$ $(\mathrm{ER} \alpha$ and $\mathrm{ER} \beta)$ after conversion to estradiol [2] (Figure 1).

\section{Androgens and aging}

Many cross-sectional studies have demonstrated lower concentrations of circulating and/or free $\mathrm{T}$ in elderly men [3-6]. The study by Harman [7] is the largest longitudinal evaluation of the effects of aging on male gonadal hormone function reported to date, strongly supporting the concept of an age-re- lated lowering of both total and bioavailable circulating $\mathrm{T}$ levels at a relatively constant rate, independently of obesity, illness, medications, cigarette smoking and/or alcohol intake. Moreover, a prospective cohort study about endocrine functioning in men found that the decline in total and free serum $\mathrm{T}$ is associated not only to aging, but to lifestyle as well [8], namely, nutrition and physical activity. Of note, asymptomatic hypogonadism has a high prevalence in the general US population, on average equal to $5.6 \%$ in men $30-79$ years of age, and increases with increasing age. Hence, the aging of the western countries male population will likely cause a large increase of androgen deficiency [9].

\section{Androgens effects on cardiovascular system}

\section{Androgens and heart remodeling}

Information about the important role played by the androgen receptors system on cardiovascular function has been gained by male androgen receptors-knockout mice. Experimental use of these mice with inactivated androgen receptors has providedinsights into the functional activities of androgens in adipocytes [10], brain [11], bone [12] and cardiovascular system [13].

Androgen receptors are present in cardiac myocytes of multiple species, including normal men and women, allowing androgens to modulate the cardiac phenotype and produce hypertrophy by direct, receptor-specific mechanisms [14]. The studies of Ikeda [13] demonstrated that in male mice, the androgen receptors system participates in normal 


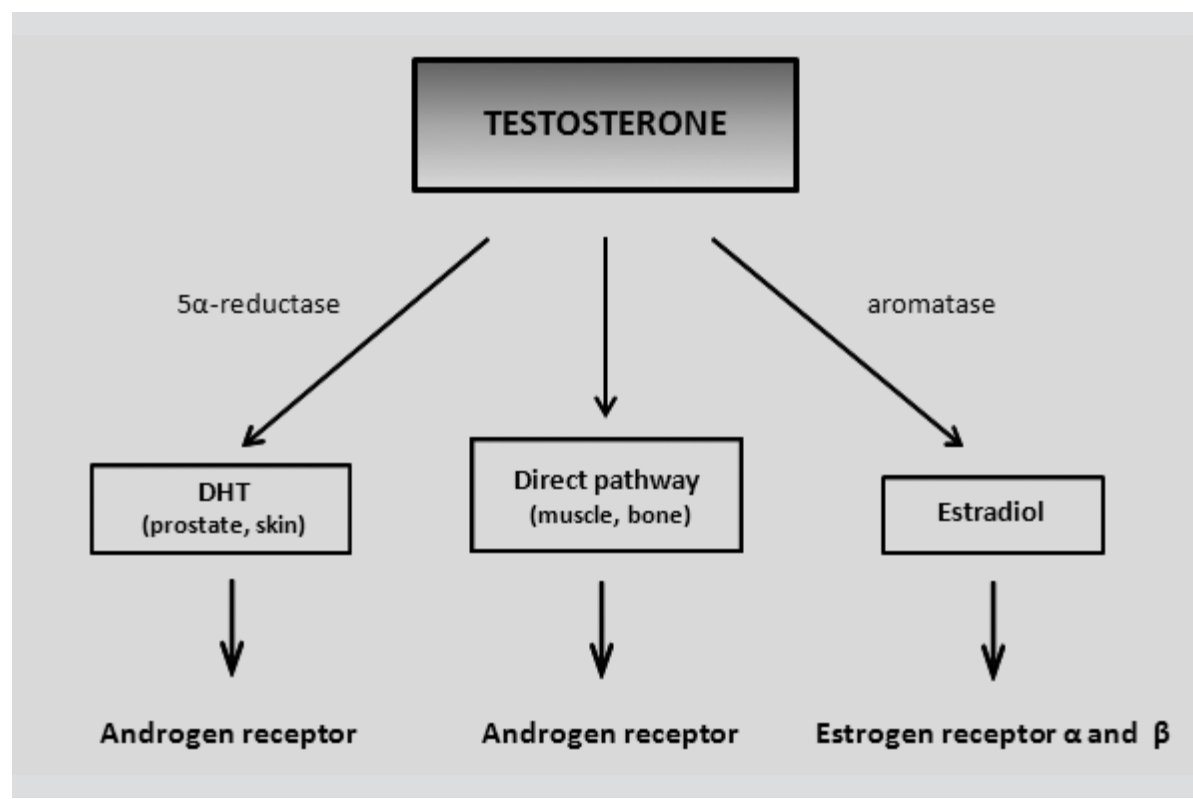

Figure 1. Pathways of testosterone action.

Testosterone directly activates the androgen receptors. In some organs rich of the $5 \alpha$-reductase enzyme, such as prostate and hair follicles, the effect of testosterone is amplified after transformation in dihydrotestosterone (DHT). Another pathway of testosterone action is through its aromatization into estrogen, that interacts with estrogen receptors $\alpha$ and/or $\beta$.

cardiac growth. Moreover, heart androgen receptors modulate adaptive hypertrophy and fibrosis during the process of cardiac remodeling under hypertrophic stress, and protect the heart from both angiotensin II-induced vascular remodeling [15] and doxorubicin-induced cardiotoxicity [16]. Androgen receptors also exist in cardiomyocytes [17] and play an important role in the modulation of cardiac hypertrophy and cardiac remodeling after myocardial infarction (MI) $[18,19]$. Of note, when estrogen levels are reduced $\mathrm{T}$ worsens cardiac dysfunction and remodeling [20]. Grohe [17] demonstrated that the enzyme cyp450 aromatase is expressed in cardiac myocytes, and that the local estrogen biosynthesis in the heart is effective to activate both the receptor $\mathrm{ER} \alpha$ and ER $\beta$. Accordingly, in the myocardium $\mathrm{T}$ operates both by activation of androgen receptors and local aromatization in estradiol acting on ER $\alpha$ and ER $\beta$. Many studies have demonstrated the preventive effect of estrogens on myocardial hypertrophy, while androgens induced cardiac hypertrophy [20-22]. These studies evidenced that $\mathrm{T}$ and estrogen interact physiologically modulating the effect on cardiac hypertrophy and contractile function, which underscores the need to evaluate both $\mathrm{T}$ and estrogen circulating levels in the clinical setting.

\section{Androgens and vascular function}

A direct effect of $\mathrm{T}$ on vascular function is mediated by the expression of the androgen receptors in vascular cells, which has been demonstrated in rabbits, dogs, monkeys and humans [23] in vascular smooth muscle cells, endothelial cells, macrophages, megakaryocytes and platelets [24]. In addition, these cells express aromatase and 17 $\beta$-hydroxysteroid-dehydrogenase, so that also estradiol can be produced locally from both T and DHEA [25-27]. ER $\alpha$, ER $\beta$ and membrane estrogen receptors are expressed in endothelial cells, smooth muscle cells, macrophages and platelets as well as in coronary arteries of monkey and man [28-31]. In rabbit aorta, $\mathrm{T}$ was found to stimulate the expression of androgen receptors and to inhibit neointimal plaque formation, indicating autoregulatory effects [23].

The effects of androgenson vascular functionare still controversial. It has long been hypothesized that androgens promote atherosclerosis, and several in vitro and in vivo studies have shown that androgens increase expression of atherogenic factors [32-35]. Conversely, other studies have demonstrated a correlation between advanced atherosclerosis and low T levels. Muller showed that serum free $\mathrm{T}$ concentrations were inversely related to the mean progression of intima-media thickness of the common carotid artery, independently of cardiovascular risk factors $[36,37]$. Low plasma $\mathrm{T}$ levels were also associated with endothelial dysfunction and poor vasodilation of brachial artery in men [38]. T-induced vasodilation was first reported in 1945 [39]. This effect involves primarily the vascular smooth muscle cells without requiring the presence of endothelium, and the rapidity of the response evidences that $\mathrm{T}$ acts through a non-genomic way. $\mathrm{T}$ induces vasodilation in all arterial beds studied, including coronary, mesenteric, iliac, renal, and femoral arteries [40], and thevasodilator responsiveness of coronary arteriesis reduced with age [41]. The direct infusion of $\mathrm{T}$ causes acute coronary vasodilation, as demonstrated by intracoronary infusion of $\mathrm{T}$ at physiological concentration in patients with coronary artery disease (CAD) $[42,43]$ and this concept is supported by numerous experimental findings both in animals and humans [32, 42, 44].

The mechanism of $\mathrm{T}$ action is the arterial androgen receptors mRNA up-regulation, that reduces neointimal plaque formation in male rabbits [23], associated with a $50 \%$ increase of the amount of androgen receptor mRNA in the arterial segments treated with $\mathrm{T}$. The beneficial effects of $\mathrm{T}$ on postinjury plaque development underlines, at least in males, the important role played by androgens in the vascular system. Physiological levels of DHT attenuated the development of atherosclerosis by androgen receptor-mediated suppression of the formation of intimal foam cells by macrophages [45]. The pathophysiological role of androgen receptors activity in the cardiovascular system has been studied in male androgen receptors-knockout mice under vascular stress [15], that exhibited exaggerated angiotensin II-induced medial thickening and perivascular fibrosis in the coronary arteries and aorta. Furthermore, physiological $\mathrm{T}$ supplementation inhibited cholesterol-enriched diet-induced 
fatty streak formation in mice with a deletion in the gene encoding the classical androgen receptor [46]. These data suggest that androgen exerts an atheroprotective effect via androgen receptor-dependent and -independent signaling.

\section{Androgens and cardiac electrophysiology}

The effects of $\mathrm{T}$ on cardiac electrophysiology are poorly described, but evidence is accumulating about the impact of sex steroids on human cardiac rhythm and arrhythmias [47]. Charbit [48] showed that the difference in QT-interval duration between men and women might be explained by differences in T levels. An involvement of gonadal steroids in morphologic differences in ventricular repolarization between males and females has also been hypothesized [47, 49]. A reduced QT dispersion in heart failure patients treated with $\mathrm{T}$ has been observed [50]. Lower QTc intervals in men with higher serum $T$ levels could be due to the association of serum $\mathrm{T}$ with prolongation of the RR interval [51]. A non-genomic action of $\mathrm{T}$ and progesterone on cardiac ion channels likely contributes to gender differences in cardiac repolarization process [52]. Repolarization of canine ventricular myocardium is significantly modified by $\mathrm{T}$, but not by estrogen, in both genders. This effect is likely due to augmentation of expression of $\mathrm{K}^{+}$-channel proteins, and thus may provide protection against arrhythmias via increasing the repolarization reserve [53]. The protective role of $\mathrm{T}$ in male hearts has been evidenced by [54] and Bigi [55], who demonstrated a QTc interval $\leq 380 \mathrm{~ms}$ among professional bodybuilders abusing of anabolic steroids.

\section{Androgens and cardiac diseases}

\section{Coronary risk factors}

$\mathrm{T}$ plays an important role in metabolism regulation. Low $\mathrm{T}$ levels are associated with obesity, metabolic syndrome and diabetes in men [56, 57], and are now recognized as an independent risk factor for such diseases [58]. T replacement improves glycemic control, visceral adiposity and hypercholesterolemia in hypogonadal men with type 2 diabetes [59]. High T levelsare associated to a low incidence of type 2 diabetes in men, but not in women [60]. In a recent review, the current knowledge on the metabolic actions of $\mathrm{T}$, the effects of $\mathrm{T}$ deficiency on obesity, metabolic syndrome and type 2 diabetes and the role of T replacement are discussed [61]. In older men, lower total $\mathrm{T}$ is associated with insulin resistance independently of measures of central obesity [62]. $\mathrm{T}$ is also involved in lipid homeostasis in insulin-responsive tissues, such as liver, adipose tissue and skeletal muscle [63].

\section{Coronary artery disease and estrogens}

CAD is the leading cause of death worldwide for both men and women [64], with the prevalence of CAD being significantly higher and the life expectancy significantly shorter in men as compared to women [65]. Historically, the different prevalence of CAD between men and women has been interpreted as an estrogen-induced protective effect against atherosclerosis. This concept has been challenged by randomized clinical trials testing the effects of combined estrogen/progestin therapy in post-menopausal women, that showed no benefits as to CAD incidence [66, 67]. Furthermore, hormone replacement strategies in postmenopausal women have been associated with an increased risk of breast and endometrial malignancy and thromboembolic disease with resulting increased mortality. In a study conducted on 2763 postmenopausal women, the treatment with oral conjugated equine estrogen plus medroxyprogesterone acetate for 4.1 years did not reduce the overall rate of CAD events [66]. In addition, a recent review showed that, in elderly postmenopausal women with established $\mathrm{CAD}$, daily use of conjugated equine estrogen and combination of medroxyprogesterone acetate plus estrogen did not reduce the overall risk of MI and coronary death during an average follow-up of 4.1 years [68]. In men, estrogen plasma level is related to the incidence of CAD [69].

\section{Coronary artery disease and androgens}

The effects of androgens on CAD are even more controversial. Previous studies have evidenced an increased risk of cardiovascular risk in all ages in men after administration of $\mathrm{T}$ [70-72]. A correlation between the use of androgens and MI has been reported in body-builders using supraphysiological doses of androgens [73-81]. Such doses of androgens were considered toxic on the cardiovascular system [82, 83, 84], but no clear evidence about an epidemic of acute cardiac events has been associated with the increase of anabolic steroids abuse during the last decades $[85,86]$.

Despite these reports, an increasing body of literature indicates that men with CAD have significantly lower T levels than those without CAD. An increased development of atherosclerosis has been shown in male animals after castration and reversedwith androgen replacement therapy [46] (see above 'Androgens and vascular function'). The relationship between serum $\mathrm{T}$ level and CAD in humans has been evaluated in a complete review by $\mathrm{Wu}$ [87]. Thirty-two cross-sectional studies were analyzed; in 16 studies, a lower level of T was found in patients with CAD as compared to controls, whereas other 16 studies showed no differences in T level between patients and controls. The Caerphilly Heart Study enrolled 2512 men [88], showing a modest reduction in $\mathrm{T}$ in survivors of MI. The association, however, became not significant when adjusted for plasma insulin and triglycerides. Conversely, Phillips [89] demonstrated a significant relationship between low free $\mathrm{T}$ level and the degree of coronary occlusion in 55 men undergoing angiography. Another study on 900 men found that both total and bioavailable T were significantly lower in men with CAD than in those without [90]. Similar results were reported by Dunajska [91], who showed that men with CAD had lower total $\mathrm{T}$ levels, T/estradiol ratio and free androgen index as compared to controls; moreover, men with CAD were more insulin-resistant than controls and had an atherogenic lipid profile. A positive association between low serum androgen levels and severe internal carotid artery 
atherosclerosis in men has been evidenced by Debing at al. [92], suggesting a protective role of physiological levels of androgens from the development of atherosclerosis. Similar results have been evidenced in the study of health in Pomerania [93] and further confirmed recently [94, 95].

In women, the relationship between androgen level and CAD has been poorly investigated. In women with polycystic ovary syndrome, two longterm longitudinal studies showed no significant increase of CAD incidence [96]. High free T and androstenedione levels within the physiological range have also been correlated with reduced carotid artery atherosclerosis in premenopausal and postmenopausal women [97]. More recently, in postmenopausal women decreased $\mathrm{T}$ levels have been found to be associated with CAD independently of other risk factors. Hormonal replacement therapy tends to increase T level, which may further support the beneficial role of hormone replacement therapy in postmenopausal women [98]. Evidence of a positive association between low serum androgen levels and severe internal carotid artery atherosclerosis in postmenopausal women has been provided, and suggests that higher, but still physiological, levels of androgens in postmenopausal women have a protective role from the development of CAD [99]. He [100] showed a more complex interaction between sex hormones and CAD. In both men and postmenopausal women with angiographic CAD, there were significant differences (relative to age-matched control subjects) in sex hormone ratios, suggesting that an abnormality in sex hormones could influence coronary health. A lower estradiol-to-progesteron ratio was associated with the predisposition to coronary atherosclerosis in males, whereas lower estradiol-to-progesteronand estradiol-to-T ratios were associated with the same condition in females.

\section{Angina pectoris}

Several studies have demonstrated the effect of $\mathrm{T}$ therapy in angina pectoris and are reported in Table 1 . The first studies were reported in 1942 by Hamm [101] and Walker [102]. These authors showed that $\mathrm{T}$ supplementation in patients with angina pectoris produced significant clinical improvement, reduced cardiac symptoms and increased time to ischemia. These date have been confirmed recently [103]. English [104] found that lowdose supplemental $\mathrm{T}$ reduces exercise-induced myocardial ischemia in men with chronic stable angina. Long-term benefits of T therapy were observed during 12 months of treatment in men with low T levels and angina; $\mathrm{T}$ increased time to ischemia without side effects [105]. In a randomized study on 50 men with exercise-induced ST segment depression, Jaffe [106] showed that a treatment with T cypionate, 200 mg intramuscularly weekly, significantly reduced ST segment depression after 8 weeks of treatment; no effects were observed in the placebo group. In a crossover study, conducted on 62 men with ischemic heart disease treated with $\mathrm{T}$ undecanoate or placebo [107], angina pectoris was relieved by $77 \%$ and myocardial ischemia in ECG and Holter recordings was reduced by $69 \%$ and $75 \%$, respectively. Moreover, administration of low doses of $\mathrm{T}$ in men with chronic stable angina reduced exercise-induced myocardial ischemia [104], resulting in an increase in time to $1-\mathrm{mm}$ ST-segment depression after 12 weeks of treatment.

\section{Myocardial infarction}

A limited number of studies are available on the relationship between T levels and MI. After MI in male patients, a transient decrease in T has been observed [112]. Chronic T administration showed no detrimental effects on left ventricular remodeling

Table 1. - Effect of testosterone treatment in men with coronary artery disease

\begin{tabular}{|c|c|c|c|c|c|}
\hline & & $\begin{array}{c}\text { Patient } \\
\text { n. }\end{array}$ & Dosage & $\begin{array}{c}\text { Treatment } \\
\text { duration }\end{array}$ & $\begin{array}{c}\text { Clinical } \\
\text { effect }\end{array}$ \\
\hline \multirow{7}{*}{ Chronic administration } & Hamm L 101 & 7 & $75 \mathrm{mg} /$ week & $1 / 2$ months & $\Uparrow$ \\
\hline & Walker TC 102 & 12 & $100 \rightarrow 10 \mathrm{mg} /$ day & 4 months & $\Uparrow$ \\
\hline & Sigler LH 108 & 16 & $50 \mathrm{mg} /$ week & 6/7 weeks & $\Uparrow$ \\
\hline & Jaffe MD 106 & 50 & $200 \mathrm{mg} /$ week & 2 months & $\Uparrow$ \\
\hline & Wu SZ 107 & 62 & $40-120 \mathrm{mg} /$ day & 1 month & $\Uparrow$ \\
\hline & English KM 104 & 46 & $5 \mathrm{mg} /$ day & 3 months & $\Uparrow$ \\
\hline & Mathur A 105 & 15 & $1 \mathrm{~g} / 3$ months & 12 months & $\Uparrow$ \\
\hline \multirow{3}{*}{ Acute administration } & Webb CM 109 & 14 & $2.3 \mathrm{mg}$ i.v. & $10 \mathrm{~min}$ & $\Uparrow$ \\
\hline & Rosano GM 110 & 14 & $2.5 \mathrm{mg}$ i.v. & $5 \min$ & $\Uparrow$ \\
\hline & Thompson PD 111 & 32 & $\begin{array}{l}\text { 2-6 times baseline } \\
\text { plasmatic level }\end{array}$ & $20 \mathrm{~min}$ & - \\
\hline
\end{tabular}

The clinical effect cumulates the reduction of the number of anginal episodes and both the prolongation of time to and the increase of heart rate at ischemic threshold during ergometric stress test.

$\Uparrow=$ clinical improvement; - = no effect. 
after MI [113]. In a study conducted on 65 regularly menstruating women aged 33-48 years with recent MI, a significantly higher concentration of $\mathrm{T}$ was found in women with a family history of CAD than in those without [114]. Due to the young age of these women, data are not conclusive and need verification.

\section{Chronic heart failure}

Several authors have considered the effects of T administration in chronic heart failure (CHF) patients at physiological doses, evidencing positive clinical outcomes [115-119]. In patients with CHF, a low level of plasma $\mathrm{T}$ has been observed [120-122]. Particularly, CHF due to idiopathic dilated cardiomyopathy is associated with a significant decrease in growth hormone, insulin-like growth factor 1 and $\mathrm{T}$ concentrations [122], underlying the concept that a catabolic state is strictly related to this clinical condition. Wehr [123] showed that low free $\mathrm{T}$ level is independently associated with increased CHF mortality, with no association with total T levels. The T treatment in men with CHF determined a significant improvement in exercise capacity and symptoms [115]. Anabolic hormones (T, DHEA sulfate, insulin-like growth factor 1) are related to physical capacity in healthy men, and in CHF patients low circulating $\mathrm{T}$ are independent predictors of exercise intolerance [124].

In a randomized double-blind placebo-controlled trial, $\mathrm{T}$ administration for a 12-month period in men with moderate-to-severe CHF was associated to an improvement in exercise capacity and symptoms, without changes in muscular strength [115]. In a similar protocol, T replacement was studied in men with moderate-to-severe CHF; T therapy improved exercise capacity and NYHA class compared with placebo [117]. Pugh [118] demonstrated that the administration of $\mathrm{T}$ increases cardiac output acutely, apparently via a reduction of left ventricular afterload. In a recent review [125], $\mathrm{T}$ appears to be a promising therapy to improve exercise capacity in patients with CHF. Caminiti [116] showed that longacting $\mathrm{T}$ therapy improves exercise capacity, muscle strength, glucose metabolism and baroreflex sensitivity in men with CHF. T therapy improved both peak $\mathrm{VO}_{2}$ and ventilatory efficiency, as assessed by the $\mathrm{VE} / \mathrm{VCO}_{2}$ slope.

$\mathrm{T}$ benefits seem to be mediated by metabolic and peripheral effects. Recently, T supplementation has been used in a 12-week program of exercise rehabilitation in elderly male patients with CHF and a low $\mathrm{T}$ status,positively impacting on a range of key health outcomes [126]. Iellamo [119] showed that women with stable CHF who received $\mathrm{T}$ transdermal patch, improved functional capacity, insulin resistance and muscle strength without side effects. In a recent meta-analysis, Toma [125] observed that $\mathrm{T}$ appears to be a promising therapy to improve exercise capacity in patients with CHF.

\section{Testosterone and prognosis}

Recent epidemiological studies revealed that low $\mathrm{T}$ levels in men were associated with higher cardiovascular mortality rates [90, 127-131]. Low plasma level of $\mathrm{T}$ and estradiol predict mortality in elderly men [129]. Furthermore, anti-androgen therapy in men affected by prostate cancer is associated with significant increases in the risk of CAD and incident heart failure [132]. Moreover, in men treated by orchiectomy, a twofold increase of CAD mortality over a 10-year period has been demonstrated [133].

Shores [134], using the Veteran's Affairs clinical database, reported that men with low $\mathrm{T}$ level had a $88 \%$ relative increase in all-cause mortality risk when compared with those with normal $\mathrm{T}$ levels, and concluded that hypotestosteronemia was a marker of increased mortality risk. An increased risk of death associated with the decline in anabolic hormone levels during a 6-year follow-up was reported in the InChianty study [135]. Laughlin [128] studied a group of 794 men for 20 years, and found that the risk of death was $44 \%$ greater between the lowest and highest quartiles of total $\mathrm{T}$ after adjusting for age, adiposity and lifestyle choices. The European Prospective Investigation in Norfolk [127] investigated all-cause and cardiovascular mortality in 11606 healthy men between 40 and 79 years of age, observing a statistically significant association between baseline serum $\mathrm{T}$ level and all-cause, cardiovascular- and cancer-related death. The authors concluded that $\mathrm{T}$ concentrations are inversely related to cardiovascular and all-cause mortality. Recently, Malkin [90] followed 930 men with angiographycally proven CAD over a 7 -year period, and found that in androgen-deficient men the mortality was $21 \%$ versus $12 \%$ in the eugonadal group. Furthermore, the biological available $\mathrm{T}$ - and not total $\mathrm{T}$ - was significantly associated to all-cause and cardiovascular mortality (Figure 2). This data suggest that bioavailable $\mathrm{T}$ is the most sensitive assay for mortality risk stratification.

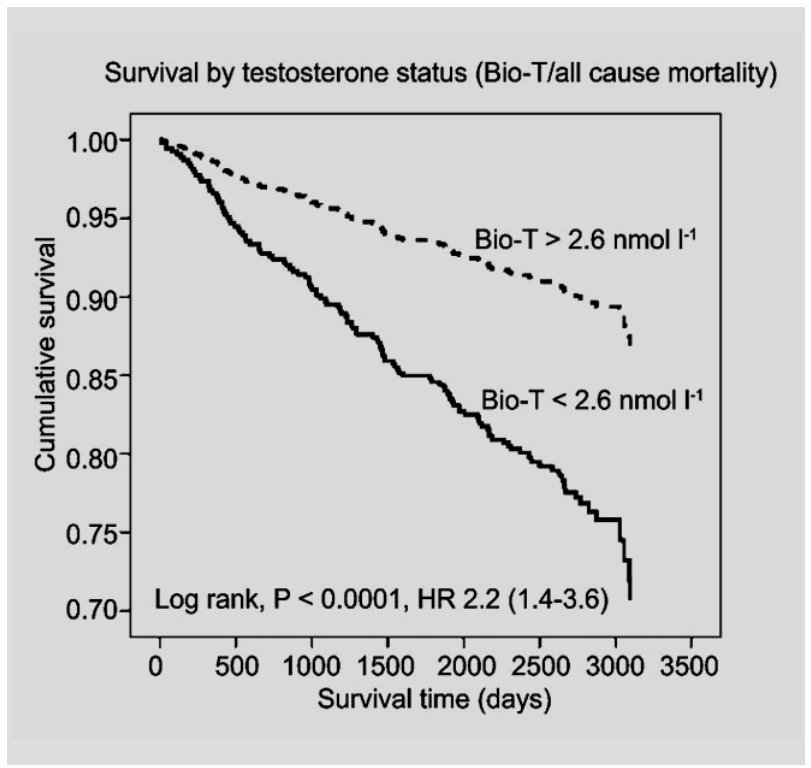

Figure 2. - Survival curves of all-cause mortality based on bio-available testosterone (Bio-T) levels.

The solid line represents patients with baseline Bio-T less than $2.6 \mathrm{nmol} / \mathrm{l}$, the broken line represents patients with Bio-T greater than $2.6 \mathrm{nmol} / \mathrm{l}$. Follow-up duration was $6.9 \pm 2.1$ years.

$\mathrm{HR}=$ hazard ratio.

Reproduced with permission from Malkin [90]. 


\section{Conclusions}

Although androgens have been considered deleterious for the cardiovascular system, recent data have demonstrated favorable T effects on cardiac and vascular remodeling and clinical outcome. However, Ruige [136] in a recent review affirms that the cardiovascular risk-benefit profile of $\mathrm{T}$ therapy remains largely evasive in view of a lack of well-designed and adequately powered randomized clinical trials. Discrepancies between studies might be explained by differences in methodology, dose and duration of $\mathrm{T}$ administration, and effects of other important hormones, such as estrogens and insulin-like growth factor 1 . In any case, a large body of clinical evidence underlines that low plasma $\mathrm{T}$ levels should be considered a risk factor for cardiovascular disease, and that the evaluation of sex steroids should be included in the routine clinical evaluation of cardiac patients. A better understanding of the mechanism regulating the effects of $\mathrm{T}$ on cardiovascular system could lead to novel therapeutic strategies in several cardiac patient populations, such as CHF patients and patients who recently underwent cardiac surgery.

\section{Riassunto}

Sebbene gli androgeni siano stati considerati dannosi per il sistema cardiovascolare, dati recenti hanno dimostrato effetti favorevoli del testosterone sul rimodellamento cardiaco e vascolare e sulla prognosi. Tuttavia, il rapporto rischio-beneficio cardiovascolare della terapia con testosterone rimane elusivo per la mancanza di trial clinici randomizzati ben disegnati e dotati di adeguata potenza statistica. In ogni caso, una notevole evidenza clinica suggerisce che bassi livelli di testosterone plasmatico dovrebbero essere considerati un fattore di rischio cardiovascolare, e che il dosaggio degli steroidi sessuali dovrebbe essere incluso nella routine clinica dei pazienti cardiopatici. Una miglior comprensione dei meccanismi che regolano gli effetti del testosterone sul sistema cardiovascolare potrebbe condurre a nuove strategie terapeutiche in molte popolazioni di pazienti cardiopatici, quali quelli con scompenso cardiaco cronico e quelli recentemente sottoposti a cardiochirurgia.

Parole chiave: testosterone, androgeni, cardiopatia, rischio cardiovascolare.

\section{ABBREVIAZIONI}

$\mathrm{T}=$ testosterone

DHT $=$ dihydrotestosterone

DHEA $=$ dehydroepiandrosterone

$\mathrm{ER} \alpha=$ estrogen receptors $\alpha$

$\mathrm{ER} \beta=$ estrogen receptors $\beta$

$\mathrm{MI}=$ myocardial infarction

$\mathrm{CAD}=$ coronary artery disease

NYHA = New York Heart Association

\section{References}

1. Dunn JF, Nisula BC, Rodbard D. Transport of steroid hormones: Binding of 21 endogenous steroids to both testosterone-binding globulin and corticosteroid-binding globulin in human plasma. Journal of Clinical Endocrinology and Metabolism 1981; 53: 58-68.

2. Kuiper GG, Enmark E, Pelto-Huikko M, Nilsson S, Gustafsson JA. Cloning of a novel receptor expressed in rat prostate and ovary. Proceedings of the National Academy of Sciences of the United States of America 1996; 93 : 5925-5930.

3. Vermeulen A, Rubens R, Verdonck L. Testosterone secretion and metabolism in male senescence. Journal of Clinical Endocrinology and Metabolism. 1972; 34: 730-735.

4. Bremner WJ, Vitiello MV, Prinz PN. Loss of circadian rhythmicity in blood testosterone levels with aging in normal men. Journal of Clinical Endocrinology and Metabolism 1983; 56: 1278-1281.

5. Tenover JS, Matsumoto AM, Plymate SR, Bremner WJ. The effects of aging in normal men on bioavailable testosterone and luteinizing hormone secretion: Response to clomiphene citrate. Journal of Clinical Endocrinology and Metabolism 1987; 65: 1118-1126.

6. Gray A, Berlin JA, McKinlay JB, Longcope C. An examination of research design effects on the association of testosterone and male aging: Results of a meta-analysis. Journal of Clinical Epidemiology 1991; 44: 671-684.

7. Harman SM. Testosterone in older men after the institute of medicine report: Where do we go from here? Climacteric 2005; 8: 124-135.

8. Travison TG, Araujo AB, Kupelian V, O'Donnell AB, McKinlay JB. The relative contributions of aging, health, and lifestyle factors to serum testosterone decline in men. Journal of Clinical Endocrinology and Metabolism 2007; 92: 549-555.

9. Araujo AB, Esche GR, Kupelian V, et al. Prevalence of symptomatic androgen deficiency in men. Journal of Clinical Endocrinology and Metabolism. 2007; 92: 4241-4247.

10. Sato T, Matsumoto T, Yamada T, Watanabe T, Kawano $\mathrm{H}$, Kato S. Late onset of obesity in male androgen receptor-deficient (arko) mice. Biochemical and Biophysical Research Communications 2003; 300: 167-171.

11. Sato T, Matsumoto T, Kawano H, et al. Brain masculinization requires androgen receptor function. Proceedings of the National Academy of Sciences of the United States of America 2004; 101: 1673-1678.

12. Kawano H, Sato T, Yamada T, et al. Suppressive function of androgen receptor in bone resorption. Proceedings of the National Academy of Sciences of the United States of America 2003; 100: 9416-9421.

13. Ikeda Y, Aihara K, Sato T, et al. Androgen receptor gene knockout male mice exhibit impaired cardiac growth and exacerbation of angiotensin ii-induced cardiac fibrosis. Journal of Biological Chemistry 2005; 280: 29661-29666.

14. Marsh JD, Lehmann MH, Ritchie RH, Gwathmey JK, Green GE, Schiebinger RJ. Androgen receptors mediate hypertrophy in cardiac myocytes. Circulation 1998; 98 : 256-261.

15. Ikeda Y, Aihara K, Yoshida S, et al. Androgen-androgen receptor system protects against angiotensin ii-induced vascular remodeling. Endocrinology 2009; 150: 2857-2864.

16. Ikeda Y, Aihara K, Akaike M, et al. Androgen receptor counteracts doxorubicin-induced cardiotoxicity in male mice. Molecular Endocrinology 2010; 24: 1338-1348.

17. Grohe C, Kahlert S, Lobbert K, Vetter H. Expression of oestrogen receptor alpha and beta in rat heart: Role of local oestrogen synthesis. Journal of Endocrinology 1998; 156: R1-7.

18. Marcus R, Krause L, Weder AB, Dominguez-Meja A, Schork NJ, Julius S. Sex-specific determinants of increased left ventricular mass in the tecumseh blood pressure study. Circulation 1994; 90: 928-936.

19. Mendelsohn ME, Karas RH. Estrogen and the blood vessel wall. Current Opinions in Cardiology 1994; 9: 619-626.

20. Cavasin MA, Sankey SS, Yu AL, Menon S, Yang XP. Estrogen and testosterone have opposing effects on chronic cardiac remodeling and function in mice with myocardial 
infarction. American Journal of Physiology. Heart and Circulatory Physiology 2003; 284: H1560-1569.

21. Weinberg EO, Thienelt CD, Katz SE, et al. Gender differences in molecular remodeling in pressure overload hypertrophy. Journal of the American College of Cardiology 1999; 34: 264-273.

22. Malhotra A, Buttrick P, Scheuer J. Effects of sex hormones on development of physiological and pathological cardiac hypertrophy in male and female rats. American Journal of Physiology 1990; 259: H866-871.

23. Hanke H, Lenz C, Hess B, Spindler KD, Weidemann W. Effect of testosterone on plaque development and androgen receptor expression in the arterial vessel wall. Circulation 2001; 103: 1382-1385.

24. Fujimoto R, Morimoto I, Morita E, Sugimoto H, Ito Y, eto $\mathrm{S}$. Androgen receptors, 5 alpha-reductase activity and androgen-dependent proliferation of vascular smooth muscle cells. Journal of Steroid Biochemistry and Molecular Biology 1994; 50: 169-174.

25. Harada N, Sasano H, Murakami H, Ohkuma T, Nagura H, Takagi Y. Localized expression of aromatase in human vascular tissues. Circulation Research 1999; 84: 1285-1291.

26. Diano S, Horvath TL, Mor G, et al. Aromatase and estrogen receptor immunoreactivity in the coronary arteries of monkeys and human subjects. Menopause 1999; 6: 21-28.

27. Schmidt M, Kreutz M, Loffler G, Scholmerich J, Straub $\mathrm{RH}$. Conversion of dehydroepiandrosterone to downstream steroid hormones in macrophages. Journal of Endocrinology 2000; 164: 161-169.

28. Karas RH, Patterson BL, Mendelsohn ME. Human vascular smooth muscle cells contain functional estrogen receptor. Circulation 1994; 89: 1943-1950.

29. Losordo DW, Kearney M, Kim EA, Jekanowski J, Isner JM. Variable expression of the estrogen receptor in normal and atherosclerotic coronary arteries of premenopausal women. Circulation 1994; 89: 1501-1510.

30. Hodges YK, Tung L, Yan XD, Graham JD, Horwitz KB, Horwitz LD. Estrogen receptors alpha and beta: Prevalence of estrogen receptor beta mrna in human vascular smooth muscle and transcriptional effects. Circulation 2000; 101: 1792-1798.

31. Mendelsohn ME, Karas RH. The protective effects of estrogen on the cardiovascular system. New England Journal of Medicine 1999; 340: 1801-1811.

32. Adams MR, Williams JK, Kaplan JR. Effects of androgens on coronary artery atherosclerosis and atherosclerosis-related impairment of vascular responsiveness. Arteriosclerosis, Thrombosis, and Vascular Biology 1995; 15: 562-570.

33. McCrohon JA, Jessup W, Handelsman DJ, Celermajer DS. Androgen exposure increases human monocyte adhesion to vascular endothelium and endothelial cell expression of vascular cell adhesion molecule-1. Circulation 1999; 99: 2317-2322.

34. Ng MK, Quinn CM, McCrohon JA, et al. Androgens upregulate atherosclerosis-related genes in macrophages from males but not females: Molecular insights into gender differences in atherosclerosis. Journal of the American College of Cardiology 2003; 42: 1306-1313.

35. Nheu L, Nazareth L, Xu GY, et al. Physiological effects of androgens on human vascular endothelial and smooth muscle cells in culture. Steroids 2011; 76: 1590-1596.

36. Muller M, van den Beld AW, Bots ML, Grobbee DE, Lamberts SW, van der Schouw YT. Endogenous sex hormones and progression of carotid atherosclerosis in elderly men. Circulation 2004; 109: 2074-2079.

37. Makinen J, Jarvisalo MJ, Pollanen $\mathrm{P}$, et al. Increased carotid atherosclerosis in andropausal middle-aged men. Journal of the American College of Cardiology 2005; 45: 1603-1608.

38. Akishita M, Hashimoto M, Ohike Y, et al. Low testosterone level is an independent determinant of endothelial dysfunction in men. Hypertension Research 2007; 30: 1029-1034
39. Liu PY, Death AK, Handelsman DJ. Androgens and cardiovascular disease. Endocrine Reviews 2003; 24: 313-340.

40. Molinari C, Battaglia A, Grossini E, Mary DA, Vassanelli C, Vacca G. The effect of testosterone on regional blood flow in prepubertal anaesthetized pigs. The Journal of Physiology 2002; 543: 365-372.

41. English KM, Jones RD, Jones TH, Morice AH, Channer KS. Aging reduces the responsiveness of coronary arteries from male wistar rats to the vasodilatory action of testosterone. Clinical Science 2000; 99: 77-82

42. Webb CM, McNeill JG, Hayward CS, de Zeigler D, Collins P. Effects of testosterone on coronary vasomotor regulation in men with coronary heart disease. Circulation 1999; 100: 1690-1696.

43. Chou TM, Sudhir K, Hutchison SJ, et al. Testosterone induces dilation of canine coronary conductance and resistance arteries in vivo. Circulation 1996; 94: 2614-2619.

44. Costarella CE, Stallone JN, Rutecki GW, Whittier FC. Testosterone causes direct relaxation of rat thoracic aorta. Journal of Pharmacology and Experimental Therapeutics 1996; 277: 34-39.

45. Qiu Y, Yanase T, Hu H, et al. Dihydrotestosterone suppresses foam cell formation and attenuates atherosclerosis development. Endocrinology 2010; 151: 3307-3316.

46. Nettleship JE, Jones TH, Channer KS, Jones RD. Physiological testosterone replacement therapy attenuates fatty streak formation and improves high-density lipoprotein cholesterol in the tfm mouse: An effect that is independent of the classic androgen receptor. Circulation 2007; 116: 2427-2434.

47. Pham TV, Rosen MR. Sex, hormones, and repolarization. Cardiovascular Research 2002; 53: 740-751.

48. Charbit B, Christin-Maitre S, Demolis JL, Soustre E, Young J, Funck-Brentano C. Effects of testosterone on ventricular repolarization in hypogonadic men. American Journal of Cardiology 2009; 103: 887-890.

49. Surawicz B, Parikh SR. Differences between ventricular repolarization in men and women: Description, mechanism and implications. Annals of Noninvasive Electrocardiology 2003; 8: 333-340.

50. Malkin CJ, Morris PD, Pugh PJ, English KM, Channer KS. Effect of testosterone therapy on qt dispersion in men with heart failure. American Journal of Cardiology 2003; 92: 1241-1243.

51. van Noord C, Dorr M, Sturkenboom MC, et al. The association of serum testosterone levels and ventricular repolarization. European Journal of Epidemiology 2010; 25: 21-28.

52. Kurokawa J, Furukawa T. Non-genomic action of sex steroid hormones and cardiac repolarization. Biological \&Pharmaceutical Bulletin 2013; 36: 8-12.

53. Fulop L, Banyasz T, Szabo G, et al. Effects of sex hormones on ecg parameters and expression of cardiac ion channels in dogs. Acta Physiologica 2006; 188: 163-171.

54. James AF, Choisy SC, Hancox JC. Recent advances in understanding sex differences in cardiac repolarization. Progress in Biophysics and Molecular Biology 2007; 94: 265-319.

55. Bigi MA, Aslani A, Aslani A. Short qt interval: A novel predictor of androgen abuse in strength trained athletes. Annals of Noninvasive Electrocardiology 2009; 14: 35-39.

56. Grossmann M. Low testosterone in men with type 2 diabetes: Significance and treatment. Journal of Clinical Endocrinology and Metabolism 2011; 96: 2341-2353.

57. Stanworth RD, Jones TH. Testosterone in obesity, metabolic syndrome and type 2 diabetes. Frontiers of Hormone Research 2009; 37: 74-90.

58. Jones TH. Effects of testosterone on type 2 diabetes and components of the metabolic syndrome. Journal of Diabetes 2010; 2: 146-156.

59. Kapoor D, Goodwin E, Channer KS, Jones TH. Testosterone replacement therapy improves insulin resistance, 
glycaemic control, visceral adiposity and hypercholesterolaemia in hypogonadal men with type 2 diabetes. $E u$ ropean Journal of Endocrinology 2006; 154: 899-906.

60. Ding EL, Song Y, Malik VS, Liu S. Sex differences of endogenous sex hormones and risk of type 2 diabetes: A systematic review and meta-analysis. JAMA 2006; 295: 1288-1299.

61. Kelly DM, Jones TH. Testosterone: A metabolic hormone in health and disease. Journal of Endocrinology 2013; 217: R25-45.

62. Yeap BB, Chubb SA, Hyde Z, et al. Lower serum testosterone is independently associated with insulin resistance in non-diabetic older men: The health in men study. European Journal of Endocrinology 2009; 161: 591-598.

63. Rao PM, Kelly DM, Jones TH. Testosterone and insulin resistance in the metabolic syndrome and $\mathrm{t} 2 \mathrm{dm}$ in men. Nature reviews. Endocrinology 2013; 9: 479-493.

64. Lloyd-Jones D, Adams R, Carnethon M, et al. Heart disease and stroke statistics-2009 update: A report from the american heart association statistics committee and stroke statistics subcommittee. Circulation 2009; 119: e21-181.

65. Kalin MF, Zumoff B. Sex hormones and coronary disease: A review of the clinical studies. Steroids 1990; 55: 330-352.

66. Hulley S, Grady D, Bush T, et al. Randomized trial of estrogen plus progestin for secondary prevention of coronary heart disease in postmenopausal women. Heart and estrogen/progestin replacement study (hers) research group. JAMA 1998; 280: 605-613.

67. Rossouw JE, Anderson GL, Prentice RL, et al. Risks and benefits of estrogen plus progestin in healthy postmenopausal women: Principal results from the women's health initiative randomized controlled trial. JAMA 2002; 288: 321-333.

68. Jyotsna VP. Postmenopausal hormonal therapy: Current status. Indian Journal of Endocrinology and Metabolism 2013; 17: S45-S49.

69. Callou de Sa EQ, Feijo de Sa FC, e Silva Rde S, et al. Endogenous oestradiol but not testosterone is related to coronary artery disease in men. Clinical Endocrinology 2011; 75: 177-183.

70. Calof OM, Singh AB, Lee ML, et al. Adverse events associated with testosterone replacement in middle-aged and older men: A meta-analysis of randomized, placebo-controlled trials. Journal of Gerontology. Series A, Biological Sciences and Medical Sciences 2005; 60: 1451-1457.

71. Haddad RM, Kennedy CC, Caples SM, et al. Testosterone and cardiovascular risk in men: A systematic review and meta-analysis of randomized placebo-controlled trials. Mayo Clinic Proceedings 2007; 82: 29-39.

72. Fernandez-Balsells MM, Murad MH, Lane M, Lampropulos JF, et al. Clinical review 1: Adverse effects of testosterone therapy in adult men: A systematic review and meta-analysis. Journal of Clinical Endocrinology and Metabolism 2010; 95: 2560-2575.

73. Huie MJ. An acute myocardial infarction occurring in an anabolic steroid user. Medicine and Science in Sports and Exercise 1994; 26: 408-413.

74. Wysoczanski M, Rachko M, Bergmann SR. Acute myocardial infarction in a young man using anabolic steroids. Angiology 2008; 59: 376-378.

75. Stergiopoulos K, Brennan JJ, Mathews R, Setaro JF, Kort $\mathrm{S}$. Anabolic steroids, acute myocardial infarction and polycythemia: A case report and review of the literature. Vascular Health and Risk Management 2008; 4: 1475-1480.

76. Kennedy C. Myocardial infarction in association with misuse of anabolic steroids. Ulster Medical Journal 1993; 62: 174-176.

77. McNutt RA, Ferenchick GS, Kirlin PC, Hamlin NJ. Acute myocardial infarction in a 22-year-old world class weight lifter using anabolic steroids. American Journal of Cardiology 1988; 62: 164.

78. Bowman S. Anabolic steroids and infarction. BMJ 1990; 300: 750 .
79. Goldstein DR, Dobbs T, Krull B, Plumb VJ. Clenbuterol and anabolic steroids: A previously unreported cause of myocardial infarction with normal coronary arteriograms. Southern Medical Journal 1998; 91: 780-784.

80. Fisher M, Appleby M, Rittoo D, Cotter L. Myocardial infarction with extensive intracoronary thrombus induced by anabolic steroids. British Journal of Clinical Practice 1996; 50: 222-223.

81. Kennedy MC, Lawrence C. Anabolic steroid abuse and cardiac death. Medical Journal of Australia 1993; 158: 346-348.

82. Weidemann W, Hanke H. Cardiovascular effects of androgens. Cardiovascular Drug Reviews 2002; 20: 175-198.

83. Sullivan ML, Martinez CM, Gennis P, Gallagher EJ. The cardiac toxicity of anabolic steroids. Progress in Cardiovascular Diseases 1998; 41: 1-15.

84. Parssinen M, Seppala T. Steroid use and long-term health risks in former athletes. Sports Medicine 2002; 32: 83-94.

85. Wilson JD. Androgen abuse by athletes. Endocrine Reviews 1988; 9: 181-199.

86. Yesalis CE, Kennedy NJ, Kopstein AN, Bahrke MS. Anabolic-androgenic steroid use in the united states. JAMA 1993; 270: 1217-1221.

87. Wu FC, von Eckardstein A. Androgens and coronary artery disease. Endocrine Reviews 2003; 24: 183-217.

88. Yarnell JW, Beswick AD, Sweetnam PM, Riad-Fahmy D. Endogenous sex hormones and ischemic heart disease in men. The caerphilly prospective study. Arteriosclerosis and Thrombosis 1993; 13: 517-520.

89. Phillips GB, Pinkernell BH, Jing TY. The association of hypotestosteronemia with coronary artery disease in men. Arteriosclerosis and Thrombosis 1994; 14: 701-706.

90. Malkin CJ, Pugh PJ, Morris PD, Asif S, Jones TH, Channer KS. Low serum testosterone and increased mortality in men with coronary heart disease. Heart 2010; 96: 1821-1825.

91. Dunajska K, Milewicz A, Szymczak J, et al. Evaluation of sex hormone levels and some metabolic factors in men with coronary atherosclerosis. Aging Male 2004; 7: 197-204.

92. Debing E, Peeters E, Duquet W, Poppe K, Velkeniers B, Van Den Brande P. Men with atherosclerotic stenosis of the carotid artery have lower testosterone levels compared with controls. International Angiology 2008; 27 : 135-141.

93. Dorr M, Wallaschofski H, Friedrich N. Association of low total testosterone levels and prevalent carotid plaques: Result of the study of health in Pomerania. European Journal of Epidemiology 2009; 24: 389-391.

94. Li L, Guo CY, Jia EZ, et al. Testosterone is negatively associated with the severity of coronary atherosclerosis in men. Asian Journal of Andrology 2012; 14: 875-878.

95. Hu X, Rui L, Zhu T, et al. Low testosterone level in middle-aged male patients with coronary artery disease. $E u$ ropean Journal of Internal Medicine 2011; 22: e133-136.

96. Pierpoint T, McKeigue PM, Isaacs AJ, Wild SH, Jacobs HS. Mortality of women with polycystic ovary syndrome at long-term follow-up. Journal of Clinical Epidemiology 1998; 51: 581-586.

97. Bernini GP, Sgro M, Moretti A, et al. Endogenous androgens and carotid intimal-medial thickness in women. Journal of Clinical Endocrinology and Metabolism 1999; 84: 2008-2012.

98. Kaczmarek A, Reczuch K, Majda J, Banasiak W, Ponikowski P. The association of lower testosterone level with coronary artery disease in postmenopausal women. International Journal of Cardiology 2003; 87: 53-57.

99. Debing E, Peeters E, Duquet W, Poppe K, Velkeniers B, Van den Brande P. Endogenous sex hormone levels in postmenopausal women undergoing carotid artery endarterectomy. European Journal of Endocrinology 2007; 156: 687-693

100. He H, Yang F, Liu X, et al. Sex hormone ratio changes in men and postmenopausal women with coronary artery disease. Menopause 2007; 14: 385-390. 
101. L. H. Testosterone propionate in the treatment of angina pectoris. Journal of Clinical Endocrinology 1942; 2: 325-328.

102. TC. W. The use of testosterone priopionate and estrogenic substance in the treatment of essential hypertension, angina and peripheral vascular disease. Journal of Clinical Endoctinology 1942; 2: 560-568.

103. Morris PD, Channer KS. Testosterone and cardiovascular disease in men. Asian Journal of Andrology 2012; 14: 428-435.

104. English KM, Steeds RP, Jones TH, Diver MJ, Channer KS. Low-dose transdermal testosterone therapy improves angina threshold in men with chronic stable angina: A randomized, double-blind, placebo-controlled study. Circulation 2000; 102: 1906-1911.

105. Mathur A, Malkin C, Saeed B, Muthusamy R, Jones TH, Channer K. Long-term benefits of testosterone replacement therapy on angina threshold and atheroma in men. European Journal of Endocrinology 2009; 161: 443-449.

106. Jaffe MD. Effect of testosterone cypionate on postexercise st segment depression. British Heart Journal 1977; 39: 1217-1222.

107. Wu SZ, Weng XZ. Therapeutic effects of an androgenic preparation on myocardial ischemia and cardiac function in 62 elderly male coronary heart disease patients. Chinese Medical Journal 1993; 106: 415-418.

108. Sieger LH. Treatment of angina pectoris by testosterone propionate. New York Journal of Medicine 1943; 43: 1424-1428.

109. Webb CM, Adamson DL, de Zeigler D, Collins P. Effect of acute testosterone on myocardial ischemia in men with coronary artery disease. American Journal of Cardiology 1999; 83: 437-439, A439.

110. Rosano GM, Leonardo F, Pagnotta P, et al. Acute anti-ischemic effect of testosterone in men with coronary artery disease. Circulation 1999; 99: 1666-1670.

111. Thompson PD, Ahlberg AW, Moyna NM, et al. Effect of intravenous testosterone on myocardial ischemia in men with coronary artery disease. American Heart Journal 2002; 143: 249-256.

112. Wang C, Chan V, Tse TF, Yeung RT. Effect of acute myocardial infarction on pituitary-testicular function. Clinical Endocrinology 1978; 9: 249-253.

113. Nahrendorf M, Frantz S, Hu K, et al. Effect of testosterone on post-myocardial infarction remodeling and function. Cardiovascular Research 2003; 57: 370-378.

114. Ablewska U, Jankowski K, Rzewuska E, Liszewska-Pfejfer D, Hryniewiecki T. A levels of endogenous gonadal hormones and their relationship with selected coronary artery disease risk factors among young women post myocardial infarction. Acta Biochimica Polonica 2011; 58: 385-389.

115. Pugh PJ, Jones RD, West JN, Jones TH, Channer KS. Testosterone treatment for men with chronic heart failure. Heart 2004; 90: 446-447.

116. Caminiti G, Volterrani M, Iellamo F, et al. Effect of longacting testosterone treatment on functional exercise capacity, skeletal muscle performance, insulin resistance, and baroreflex sensitivity in elderly patients with chronic heart failure a double-blind, placebo-controlled, randomized study. Journal of the American College of Cardiology 2009; 54: 919-927.

117. Malkin CJ, Pugh PJ, West JN, van Beek EJ, Jones TH, Channer KS. Testosterone therapy in men with moderate severity heart failure: A double-blind randomized placebo controlled trial. European Heart Journal 2006; 27: 57-64.

118. Pugh PJ, Jones TH, Channer KS. Acute haemodynamic effects of testosterone in men with chronic heart failure. European Heart Journal 2003; 24: 909-915.

119. Iellamo F, Volterrani M, Caminiti G, et al. Testosterone therapy in women with chronic heart failure: A pilot double-blind, randomized, placebo-controlled study. Journal of the American College of Cardiology 2010; 56: 1310-1316.
120. Moriyama Y, Yasue H, Yoshimura M, et al. The plasma levels of dehydroepiandrosterone sulfate are decreased in patients with chronic heart failure in proportion to the severity. Journal of Clinical Endocrinology and Metabolism 2000; 85: 1834-1840.

121. Jankowska EA, Biel B, Majda J, et al. Anabolic deficiency in men with chronic heart failure: Prevalence and detrimental impact on survival. Circulation 2006; 114: 1829-1837.

122. Kontoleon PE, Anastasiou-Nana MI, Papapetrou PD, et $a l$. Hormonal profile in patients with congestive heart failure. International Journal of Cardiology 2003; 87: 179-183.

123. Wehr E, Pilz S, Boehm BO, Marz W, Grammer T, Obermayer-Pietsch B. Low free testosterone is associated with heart failure mortality in older men referred for coronary angiography. European Journal of Heart Failure 2011; 13: $482-488$

124. Jankowska EA, Filippatos G, Ponikowska B, et al. Reduction in circulating testosterone relates to exercise capacity in men with chronic heart failure. Journal of Cardiac Failure 2009; 15: 442-450.

125. Toma M, McAlister FA, Coglianese EE, et al. Testosterone supplementation in heart failure: A meta-analysis. Circulation Heart Failure 2012; 5: 315-321.

126. Stout M, Tew GA, Doll H, et al. Testosterone therapy during exercise rehabilitation in male patients with chronic heart failure who have low testosterone status: A double-blind randomized controlled feasibility study. American Heart Journal 2012; 164: 893-901.

127. Khaw KT, Dowsett M, Folkerd E,et al. Endogenous testosterone and mortality due to all causes, cardiovascular disease, and cancer in men: European prospective investigation into cancer in norfolk (Epic-Norfolk) Prospective Population Study. Circulation 2007; 116: 2694-2701.

128. Laughlin GA, Barrett-Connor E, Bergstrom J. Low serum testosterone and mortality in older men. Journal of Clinical Endocrinology and Metabolism2008; 93: 68-75.

129. Tivesten A, Vandenput L, Labrie F, et al. Low serum testosterone and estradiol predict mortality in elderly men. Journal of Clinical Endocrinology and Metabolism 2009; 94: 2482-2488.

130. Araujo AB, Dixon JM, Suarez EA, Murad MH, Guey LT, Wittert GA. Clinical review: Endogenous testosterone and mortality in men: A systematic review and metaanalysis. Journal of Clinical Endocrinology and Metabolism 2011; 96: 3007-3019.

131. Corona G, Monami M, Boddi V, et al. Low testosterone is associated with an increased risk of mace lethality in subjects with erectile dysfunction. Journal of Sexual Medicine 2010; 7: 1557-1564.

132. Martin-Merino E, Johansson S, Morris T, Garcia Rodriguez LA. Androgen deprivation therapy and the risk of coronary heart disease and heart failure in patients with prostate cancer: A nested case-control study in UK primary care. Drug Safety 2011; 34: 1061-1077.

133. Tsai HK, D'Amico AV, Sadetsky N, Chen MH, Carroll PR. Androgen deprivation therapy for localized prostate cancer and the risk of cardiovascular mortality. Journal of the National Cancer Institute 2007; 99: 1516-1524.

134. Shores MM, Matsumoto AM, Sloan KL, Kivlahan DR. Low serum testosterone and mortality in male veterans. Archives of Internal Medicine 2006; 166: 1660-1665.

135. Maggio M, Lauretani F, Ceda GP, et al. Relationship between low levels of anabolic hormones and 6-year mortality in older men: The aging in the Chianti area (InChianti) study. Archives of Internal Medicine 2007; 167: 2249-2254.

136. Ruige JB, Ouwens DM, Kaufman JM. Beneficial and adverse effects of testosterone on the cardiovascular system in men. Journal of Clinical Endocrinology and Metabolism 2013; 98: 4300-4310. 